\title{
Invasive species grows faster, competes better, and shows greater evolution toward increased seed size and growth than exotic non-invasive congeners
}

\author{
Ryan C. Graebner - Ragan M. Callaway • \\ Daniel Montesinos
}

Received: 31 August 2011/Accepted: 4 January 2012

(C) Springer Science+Business Media B.V. 2012

\begin{abstract}
Comparisons of introduced exotics that invade and those that do not can yield important insights into the ecology of invasions. Centaurea solstitialis, C. calcitrapa, and C. sulphurea are closely related, share a similar life history and were each introduced to western North America from Southern Europe $\sim 100-200$ years ago. However, of these three species, only $C$. solstitialis has become invasive. We collected seeds from different populations for each of the three species both in the native range of Spain and the non-native range of California, measured individual seed mass, and grew plants from these seeds in a greenhouse experiment in Montana. The invasive C. solstitialis had the smallest seeds and seedlings of the three congeners. However, in contrast to its noninvasive congeners, $C$. solstitialis had the highest
\end{abstract}

Electronic supplementary material The online version of this article (doi:10.1007/s11258-012-0020-x) contains supplementary material, which is available to authorized users.

R. C. Graebner $(\bowtie) \cdot$ R. M. Callaway · D. Montesinos Division of Biological Sciences, The University of Montana, 32 Campus Dr, 59812 Missoula, MT, USA

e-mail: ryan.graebner@gmail.com

D. Montesinos

CIDE (CSIC-UV-GV), Camí de la Marjal s/n, Albal,

46470 Valencia, Spain

D. Montesinos

Center for Functional Ecology (UC), Apartado 3046, 3001-401 Coimbra, Portugal relative growth rates when grown in competition. C. solstitialis was also the only species to show significant differences in traits between populations from different ranges, with plants from the non-native range of California demonstrating greater competitive resistance, larger seed size, and larger seedling mass than plants from the native range in Spain. This suggests that $C$. solstitialis may be evolving toward larger seed and seedling sizes in this non-native range. Relative growth rate showed no inter-regional variation for any species, but was higher for C. solstitialis than its congeners when in competition, and thus may interact with the evolution of larger seeds and plant mass in ways that contribute to the extraordinary invasive success of this species.

Keywords Biogeography - Centaurea .

Competition - Congener - Invasion .

Relative growth rate $\cdot$ Seed mass

\section{Introduction}

Humans have dispersed many species far beyond their original, or native ranges, and a small proportion of these colonists have become "invaders" (Hierro et al. 2005; Williamson and Fitter 1996). Successful invasions can occur for many reasons, but may involve traits that confer disproportionally strong per capita or population-based competitive advantages (Ortega and Pearson 2005). Competition 
can have strong effects on the distribution and abundance of plant species in native systems (Brooker et al. 2005; Pennings and Callaway 1992) and similar effects might be found in the context of exotic replacement of natives during invasion (He et al. 2003, 2009; Skálová and Pyšek 2009; Vilà and Weiner 2004). However, the relative importance of these competitive mismatches for invasive success remains ambiguous and the mechanisms are poorly understood (Radford et al. 2010). For example, invaders may gain substantial competitive advantages through reduced consumer attack in non-native ranges (Kulmatiski et al. 2008; Reinhart and Callaway 2006; Vilà and Weiner 2004), through traits that differ from those of natives and to which natives may not have adapted (Inderjit et al. 2011; Kim and Lee 2010), or through selection for stronger competitive ability in non-native ranges (Ridenour et al. 2008).

Comparing the effects of invaders on species from native and non-native ranges has provided insight into the role of competition in invasions (Callaway and Aschehoug 2000; Inderjit et al. 2011), and separate comparisons of native and exotic congeners have shed light on the traits and mechanisms involved in invasions (Gerlach and Rice 2003). For example, Skálová and Pyšek (2009) conducted field experiments with invasive and native Impatiens species and found that sites dominated by native congeners could be occupied by the other species. However, plots in sites dominated by the invasive I. glandulifera could not be colonized by the other species. Comparisons of native and invasive congeners are important, but other information can be gained from comparing congeners that have been introduced to new ranges, but that vary in invasive success. To our knowledge there have been no studies of competitive effects and responses for exotic invasive and non-invasive congeners from both the native and non-native ranges.

Centaurea sulphurea, C. calcitrapa, and C. solstitialis are closely related annual species that have been introduced to California ( $C$. calcitrapa can very occasionally be biennial). In Spain, part of the native range for all three Centaurea species, $C$. calcitrapa is much more widespread than $C$. solstitialis, and $C$. sulphurea occurs only in several small populations. However after introduction to California, C. solstitialis has become an exceptionally widespread invader with strong effects on native species
(Maddox et al. 1985) while C. calcitrapa and C. sulphurea have remained quite uncommon in this non-native range. We compared several traits of these Centaurea species that are related to competitive ability: seed size, seedling size, and seedling relative growth rate, and the competitive responses of the Centaurea congeners against a native European species that is now widespread in the California grasslands where these Centaurea species occur, and one native North American grass species. We also used these traits and competitive interactions to compare plants grown from seeds collected from populations in the native and non-native ranges for each species. We tested the following hypotheses: (1) the invasive $C$. solstitialis will demonstrate a superior competitive response, or tolerance, to competition from neighbors than non-invasive congeners, (2) C. solstitialis from Californian populations will have larger seed size, seedling growth rate, and superior competitive responses than plants from Spanish populations, and (3) such biogeographic differences between populations from the native and non-native ranges will not be demonstrated for the non-invasive Centaurea congeners.

\section{Materials and methods}

Species and sites

Centaurea solstitialis, C. calcitrapa, and C. sulphurea are closely related species within the Jacea group of the Centaurea phylogeny (Garcia-Jacas et al. 2006) and have overlapping distributions both in their native range in Spain and in their non-native range in California. For all three species, the native and nonnative ranges are much larger than just these two regions (Gerlach and Rice 2003; Maddox et al. 1985), with the exception of $C$. sulphurea, for which the only known populations that occur outside of its native range are found in California. The populations we sampled in Spain were located in the north, south, east, west, and central parts of the country, whereas the populations we sampled California in were within $150 \mathrm{~km}$ to the north, south and east of San Francisco, where each of the three species was introduced initially into the United States and where population densities are very high. C. solstitialis has been in California since at least 1824 (Maddox et al. 1985) 
where it has become a highly aggressive invader possessing several traits contributing to its invasive ability, including the ability to extend its growing season further into the summer than most winter annuals (Gerlach and Rice 2003; Hierro et al. 2009). Californian populations of this invasive species possess high genetic diversity among populations, and low between-population genetic differentiation, suggesting that colonization occurred from a large number of different individuals and that there is a high rate of gene flow among populations (Sun 1997). C. calcitrapa is thought to have been introduced by 1896 at the latest (Pitcairn et al. 2002; Robbins 1940), and C. sulphurea by 1923 (Barbe 1989; Muth and Pigliucci 2006) and probably from a single introduction. As noted, neither $C$. calcitrapa nor $C$. sulphurea have shown the level of invasive success that $C$. solstitialis has seen in California. For the purposes of this article, we will consider introduced species that exhibit greater success in their introduced ranges than in their native ranges invasive species.

We collected seeds from seven different individual plants in each of seven different populations in the native range of Spain and in the non-native range in California for $C$. solstitialis and C. calcitrapa; and from each of four Spanish and three Californian populations for C. sulphurea. Populations of each of the three species were selected to be as close as possible to sampled populations of each of the other species within each range (Supplementary Table 1).

Bromus hordeaceus is a native grass from Europe and West Asia, being most common in the Mediterranean region. It has naturalized in all other continents except Antarctica, and it is widely distributed throughout the U.S. and particularly California where it is more abundant than in Mediterranean Europe. It is a wind-pollinated annual or biennial grass-forming tussocks between 10 and $100 \mathrm{~cm}$ high. Seeds were purchased from S\&S Seeds, Carpinteria, CA, USA and collected from California where it forms high density populations.

Poa secunda is a native grass from North America and particularly abundant throughout western North America. It is a wind pollinated perennial forming tussocks up to $30 \mathrm{~cm}$ tall. It is relatively short lived and populations fluctuate with annual weather conditions. Seeds were collected from California where it is a common grass species.
Seed size

We weighed and measured three seeds from each of the seven different individual plants from each population, and randomly assigned each seed to one of three different competition treatments. C. solstitialis produces seeds with a pappus and seeds without pappus seeds. Thus for each population, for three of the parent plants, we used only non-pappus seeds, and for the other four parent plants we used only pappus seeds.

\section{Seedling size}

Seeds were sown in a common garden greenhouse at the University of Montana at Missoula. Each $200 \mathrm{ml}$ pot was filled with a 50-50 mixture of 20-30 grit sand and soil from Missoula, Montana. Greenhouse temperatures were kept between 15 and $30^{\circ} \mathrm{C}$. Natural light was supplemented by metal halide bulbs, and PAR during the day peak at $\approx 1,500 \mu \mathrm{mol} \mathrm{m} \mathrm{m}^{-2} \mathrm{~s}^{-1}$. For each set of three individually weighed and marked seeds, collected from each parent plant, and for each of the three species, one seed was planted alone as a control, one seed was planted in competition with $P$. secunda, a North American native, and one seed was planted in competition $B$. hordeaceus, a European native. Because of research indicating the importance of invaders possessing strong competitive responses, or tolerances, in interactions with native species (MacDougall and Turkington 2004), we strongly skewed the competitive environment to emphasize the competitive tolerance of the Centaurea species by planting five seeds of the grasses around each Centaurea seed. However, this approach caused the competitive effects of the Centaurea congeners to be negligible thus the effects of Centaurea species are not presented here. Seedlings were allowed to grow for 79 days before being harvested. We dried the roots and shoots for $48 \mathrm{~h}$ at $90^{\circ} \mathrm{C}$ and then weighed the total dry mass. RGR were calculated by dividing seedling mass by seed mass by the total number of days between germination and harvest (79 days) to obtain an index as $\mathrm{g} \mathrm{g}^{-1} \mathrm{day}^{-1}$.

\section{Statistical analysis}

Data were analyzed with R 2.13.0 by using linear mixed-effects models as described in Laird and Ware 
(1982). Seed mass, seedling mass and relative growth rate were dependent variables nested within parent plant and population for each of the three species. Continent and competition treatment were fixed factors. For C. solstitialis pappus and non-pappus seeds were pooled together unless otherwise stated, in which case pappus presence was treated as a fixed factor.

\section{Results}

Seed size

Centaurea sulphurea seeds were approximately six times larger than those of the other two species (Fig. 1; $F_{\text {species }}=2660.1 ; \mathrm{df}=2,32 ; P<0.001$, Tukey post hoc $P<0.001$ and $P<0.001$ ), and seeds of $C$. calcitrapa were slightly larger than seeds of C. solstitialis (Fig. 1; Tukey post hoc $P<0.001$ ). C. solstitialis seeds collected from Californian populations weighed $50 \%$ more than seeds collected from Spanish populations (Fig. $1 ; F_{\text {continent }}=67.5 ; \mathrm{df}=$ $1,12 ; P<0.001)$. There were no differences in seed size between regions for $C$. calcitrapa ( $F_{\text {conti- }}$ $\left.{ }_{\text {nent }}=0.4 ; \mathrm{df}=1,12 ; P=0.562\right)$ or $C$. sulphurea $\left(F_{\text {continent }}=4.7 ; \mathrm{df}=1,5 ; P=0.082\right)$. When pappus presence was considered in the statistical analysis,

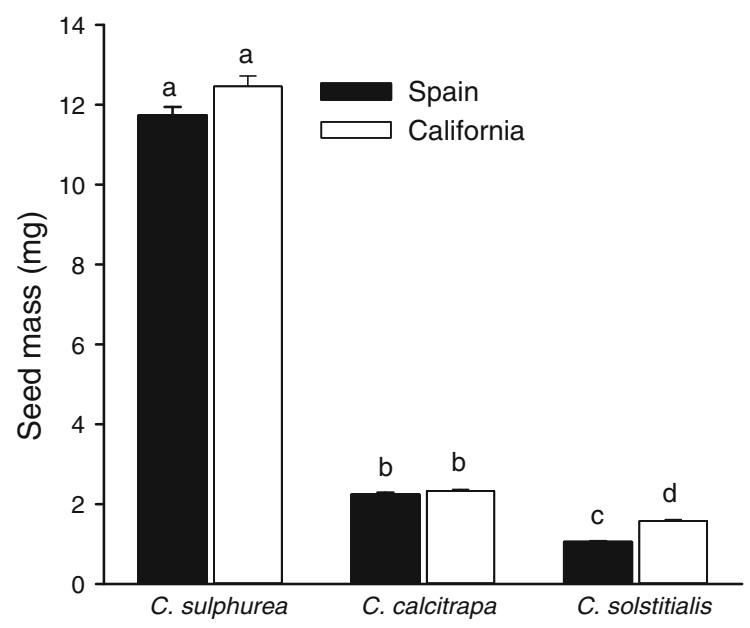

Fig. 1 Mean seed mass for each of the species and ranges. Error bars represent $1 \mathrm{SE}$ and different letters represent significant differences as determined by LMM and Tukey's post hoc tests. For Centaurea solstitialis, pappus and nonpappus seeds were pooled here
C. solstitialis seeds with a pappus were significantly larger $(1.42 \pm 0.16 \mathrm{mg}$, mean $\pm \mathrm{SE})$ than seeds without a pappus $(1.18 \pm 0.13 \mathrm{mg} ; F=51.7$; df $=1,279$; $P<0.001)$.

Plant size, growth rates, and competitive responses

At the end of the experiment $C$. sulphurea plants were over five times larger than $C$. calcitrapa and C. solstitialis plants $\left(F_{\text {species }}=32.27 ;\right.$ df $=2,25$; $\mathrm{p}=0.001 ;$ Tukey's post hoc $P<0.001)$, and C. calcitrapa plants were $40 \%$ larger than C. solstitialis plants $(P<0.001$; Fig. 2$)$. Across all competition treatments, $C$. solstitialis plants from California were $20 \%$ larger than their Spanish counterparts $\left(F_{\text {continent }}=8.52 ; \mathrm{df}=1,12 ; P=0.012\right)$. C. calcitrapa plants and $C$. sulphurea plants from California and Spain did not differ in mass between continents $\left(F_{\text {continent }}=1.95 ; \mathrm{df}=1,12 ; P=0.187\right.$ and $F_{\text {continent }}$ $=0.24 ; \mathrm{df}=1,5 ; P=0.648$, respectively). When pappus presence was considered in the statistical analysis, C. solstitialis seeds with a pappus produced significantly larger plants $(59.9 \pm 4.6 \mathrm{mg}$, mean $\pm \mathrm{SE})$ than nonpappused seeds $(44.7 \pm 4.6 \mathrm{mg} ; F=2.71 ; \mathrm{df}=4,115$; $P=0.008$ ) for both regions and across competition treatments.

In competition, the biomass of the two non-invasive congeners was reduced by both competitor species, but the total final biomass of these species was still greater than that of the invasive $C$. solstitialis (Fig. 2; $F_{\text {species }}=47.85 ; \mathrm{df}=2,29 ; P<0.001$; Tukey's post hoc $P<0.001$ and $P=0.017$ ). The European grass $B$. hordeaceus had stronger competitive effects on all three Centaurea species than the native North American $P$. secunda (Fig. 2; $F_{\text {competition } \times \text { species. }}=129.7$; df $=2,340 ; P<0.001$; Tukey's post hoc $P<0.001$ ). Importantly, the biomass of $C$. solstitialis was not reduced by competition with the North American native $P$. secunda (Tukey's post hoc, $P=0.848$ ); whereas $P$. secunda significantly reduced the biomass of the two non-invasive congeners $(P<0.001$ for each). This was true for plants grown from seed from both of the ranges. The only difference among plants for any Centaurea species between populations in the native and non-native range was for $C$. solstitialis in competition with $B$. hordeaceous, where populations from California showed greater resistance to the effect of the grass than populations from Spain $(P=0.013)$. 

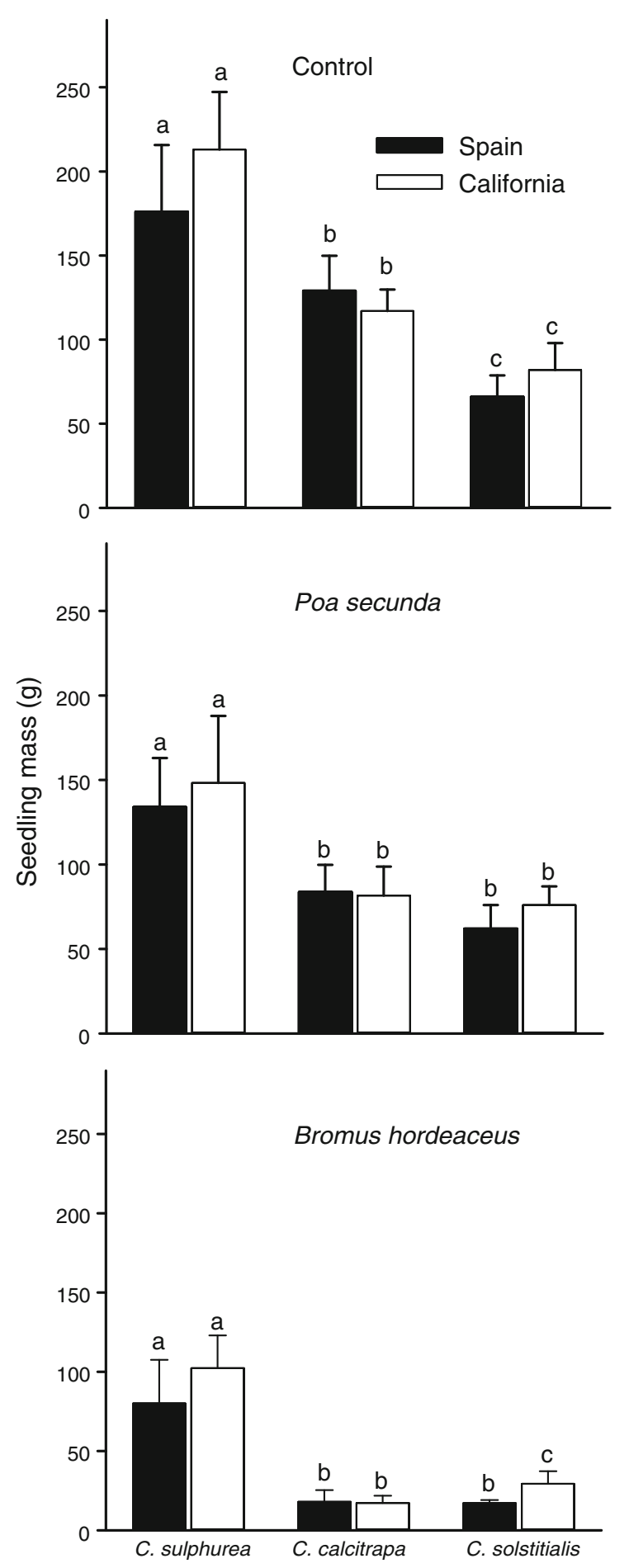

Fig. 2 Mean total plant mass for each of the Centaurea species grown from seed collected in different ranges and for each competition treatment. Error bars represent $1 \mathrm{SE}$ and different letters represent significant differences as determined by LMM and Tukey's post hoc tests
Across all competition treatments, relative growth rates (RGR) showed significant differences among species $\left(F_{\text {species }}=24.92 ; \mathrm{df}=2,29 ; P<0.001\right)$; with $C$. sulphurea showing by far the lowest mean growth rate at $0.15 \pm 0.01 \mathrm{~g} \mathrm{~g}^{-1}$ day $^{-1}$ (Tukey's post hoc $P<0.001)$ C. calcitrapa grew at $0.44 \pm$ $0.03 \mathrm{~g} \mathrm{~g}^{-1} \mathrm{day}^{-1}$, and the invasive $C$. solstitialis at $0.55 \pm 0.04 \mathrm{~g} \mathrm{~g}^{-1}$ day $^{-1}$; but these later two did not differ significantly (Tukey's post hoc $P=0.081$ ). Without competition, RGRs for $C$. calcitrapa and C. solstitialis did not differ, but both were over three times higher than the RGR of $C$. sulphurea ( $F_{\text {spe- }}$ cies $=22.43 ; \mathrm{df}=2,25 ; P<0.001$, Tukey's post hoc tests $P<0.001 ; P<0.001$ and $P=0.978$ ). Importantly, when competing with either the North American native $P$. secunda $\left(F_{\text {species }}=31.67 ; \quad \mathrm{df}=2,29\right.$; $P<0.001$, Tukey's post hoc tests $P<0.001$; $P<0.001$ and $P<0.001)$ or the European $B$. hordeaceous $\left(F_{\text {species }}=16.46 ; \mathrm{df}=2,29 ; P<0.001\right.$, Tukey's post hoc tests $P=0.591 ; P<0.001$ and $P<0.001$ ), the RGR of the invasive $C$. solstitialis was significantly higher than that of the two non-invasive congeners (Fig. 3). We found no differences in RGR between populations from Spain and California for any Centaurea species in any treatment $\left(F_{\text {continent }}=1.59\right.$; df $=1,29 ; P=0.217$ ).

\section{Discussion}

We found that the invasive $C$. solstitialis grew faster from seed to seedling (RGR) when in competition and showed greater competitive resistance (response or tolerance) to the competitive effects of a North American native than its non-invasive congeners. Furthermore, $C$. solstitialis was the only species that demonstrated evidence for evolving larger seed size, seedling size, growth rates, and greater competitive resistance in populations in its non-native range. Several previous studies have shown RGR to be higher for invasive plants than for non-invasive plants (Grotkopp et al. 2002; Burns 2004; Grotkopp et al. 2010; Kleunen et al. 2010; Dawson Fischer, and van Kleunen 2011). However, the faster growth rates and greater competitive resistance demonstrated by $C$. solstitialis had a proportionally small effect on the total mass of the species by the end of our experimental period, as the two non-invasive congeners were substantially larger than $C$. solstitialis, due to initially larger seed 

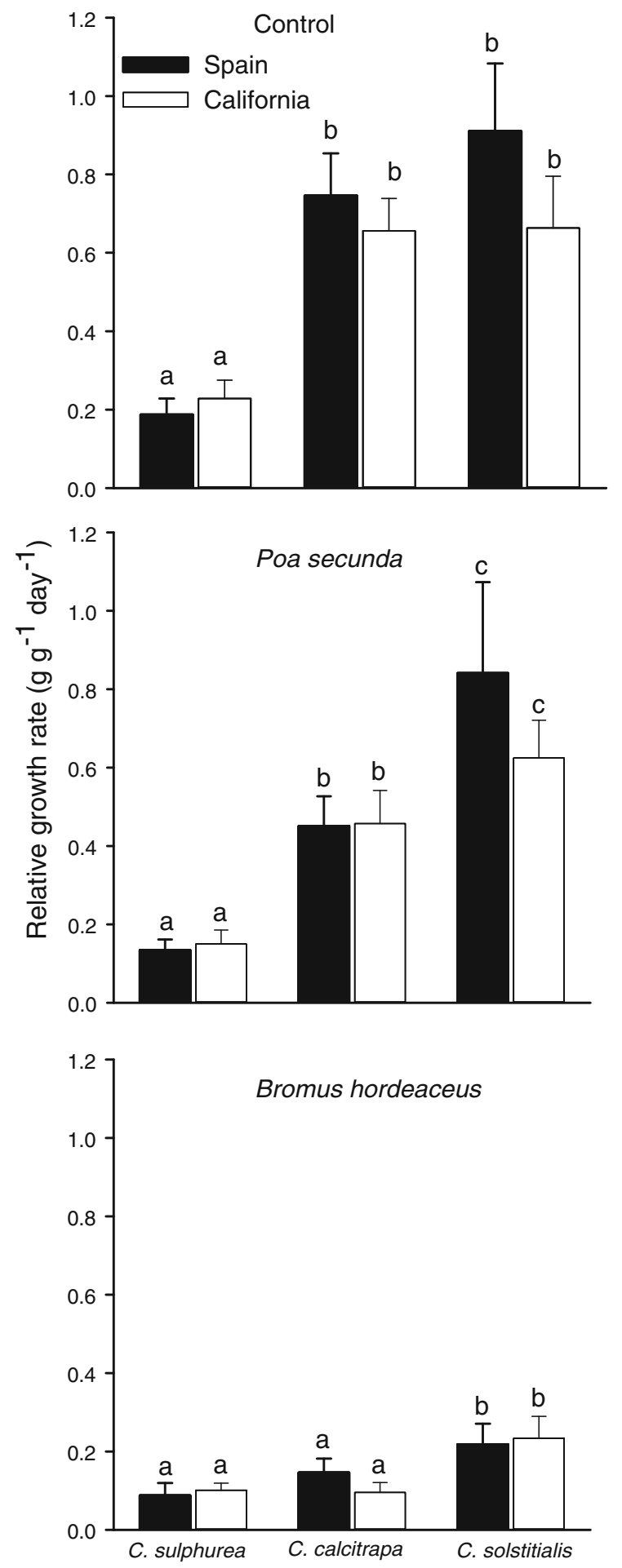

mass. Thus our results suggest that a strong competitive response, or tolerance, through the ability to maintain rapid growth while in competition, may be an
4 Fig. 3 Mean relative growth rate mass $\left(\mathrm{g} \mathrm{g}^{-1} \mathrm{day}^{-1}\right)$ for each Centaurea species, ranges in which seeds were collected, and for each competition treatment. Error bars represent $1 \mathrm{SE}$ and different letters represent significant differences as determined by LMM and Tukey's post hoc tests

important aspect of successful invasion, and that selection for larger seed size may contribute to this response. Importantly, large seeds and large total mass per se, did not correlate with increased competitive ability.

Seeds produced by the invasive $C$. solstitialis from Californian populations were significantly heavier than seeds produced by conspecifics from Spain, suggesting that local adaptation may have occurred since the time of introduction and that some aspect of the Californian environment has selected for larger seed size. C. sulphurea, which was introduced into California more recently than $C$. solstitialis (88 years vs. 187 years respectively), showed a similar but non-significant trend. Our experiment did not control for maternal effects, but Widmer et al. (2007) found that F1 seeds from $C$. solstitialis, thus likely to be more free from maternal effects, did not show different patterns than the parent seed collection. This suggests that the maternal effects of $C$. solstitialis on seed size contribute little to intercontinental differences (also see Ridenour et al. 2008). For $C$. solstitialis, seeds with pappuses produced significantly larger plants, independently of region of origin. Seed polymorphism is common in Asteraceae (Imbert 2002), and different germination behavior has been reported frequently for different seed types (Mandak and Pysek 2005; Venable et al. 1987) including for $C$. solstitialis germination (Hierro et al. 2009). Imber et al. (1997) described different size and performance for plants from different seed morphs of the annual Asteraceae Crepis sancta. Potentially, such heteromorphisms help C. solstitialis successfully explore a wide range of environmental conditions, since pappus seeds are dispersed mainly during the summer, and non-pappus seeds remain in the capitulum until autumn or winter (Callihan et al. 1993; Roche et al. 1997).

Larger seeds have greater energy reserves and generally produce bigger seedlings; however, over time this correlation tends to wane and plant size is better correlated with inherent growth rates (Westoby et al. 1992). Interestingly, species with larger seeds 
generally tend to have lower growth rates (Westoby et al. 1992), a pattern that was clear in our results. Relative growth rate emerged as an important attribute in our study, and invasive species commonly have faster RGRs than non-invasive relatives (Burns 2004; Dawson et al. 2011; Grotkopp et al. 2010; Grotkopp et al. 2002; van Kleunen et al. 2010). However, there are many other tradeoffs related to seed size that could affect exotic invasion. Small seeded species tend to disperse greater distances (Greene and Johnson 1993; Venable and Brown 1988), to have greater geographical ranges, to be more abundant in local communities than large seeded species (Guo et al. 2000), and to persist in soil seed banks longer than larger seeds (Thompson et al. 1993). Small seeds have also been shown to experience lower predation rates (Westoby et al. 1992). However, Pearson et al. (2011) found that seeds of Centaurea stoebe, a perennial invasive congener of our target species, were avoided far more by generalist granivores than native species with similar or smaller masses, suggesting that if exotic seeds are subjected to weaker selective constraints by consumers to be small, perhaps selection by competition to be larger may emerge.

The invasive $C$. solstitialis was also the only congener to demonstrate evidence for selection in the introduced range toward greater competitive ability. Across all treatments, individuals from Californian populations grew larger in total mass than individuals from Spanish populations. Such interaction strengths are likely to be important determinants of competitive outcomes. It is important to note that we harvested the Centaureas before they reached a reproductive age, so our competitive values are based on how they compete as young plants. Also, these plants were grown in artificial conditions, which may differ from conditions in the field. Testing these interactions in the field; however, risks introducing new Centaurea genotypes. Furthermore, our results only display one aspect of the way plants compete, and may miss important aspects of competition in an invasive context. For example, MacDougall and Turkington (2004) found that the extended dominance of the invader Poa pratensis in western Canadian grasslands was promoted more by strong competitive responses than competitive effects under low resource conditions. Other studies have found that species with greater competitive effects (good at suppressing other species) dominate native plant communities that are more or less at equilibrium conditions (Goldberg 1996; Goldberg and Werner 1983). We have emphasized competitive responses rather than effects, and depending on whether $C$. solstitialis functions more as a "driver" or a "passenger" as it invades (MacDougall and Turkington 2004) we may not measured important aspects of competitive interactions.

In sum, our results show greater growth rates and competitive responses for an invasive species than its non-invasive congeners, and suggest that the invasive congener has experienced selection on traits that may contribute to its competitive success in ways that might interact with higher growth and competitive ability. Other mechanisms, both related and unrelated to per capita competitive ability, appear to promote invasion by $C$. solstitialis including biogeographic differences in response to disturbance (Hierro et al. 2006), evolution of germination responses in nonnative ranges (Hierro et al. 2009), weak density dependent resistance in invaded grasslands (Munshaw and Lortie 2010), escape from soil pathogens (Andonian et al. 2011; Hierro et al. 2006), and compensatory responses to herbivory by individuals and populations (Callaway et al. 2006; Garren and Strauss 2009). However, our results contribute to understanding the role of competition in the distribution and abundance of plants (Brooker et al. 2005) and evolution in plant communities (Brooker et al. 2009; Thorpe et al. 2011), and suggest that fundamental traits affecting competitive interactions may contribute to the striking dominance of $C$. solstitialis where it is not native.

Acknowledgments Thanks to Dr. Esther Bochet for help with theory. Thanks to Dr. Susana Paula for statistical advice and for help with fieldwork. Thanks to everyone at Callaway Lab for their help with lab work. RCG was funded by the MILES/HHMI program of The University of Montana; RMC was funded by NSF-DEB 0614406 and DM was funded by the Spanish Micinn (2008-0662) and by Portuguese FCT (SFRH/BPD/72595/2010).

\section{References}

Andonian K, Hierro JL, Khetsuriani L et al (2011) Rangeexpanding populations of a globally introduced weed experience negative plant-soil feedbacks. PLoS ONE 6:e20117

Barbe GD (1989) Noxious weeds of California 1, distribution maps: Centaurea sulphurea. California Department of Food and Agriculture, Division of Plant Industry, Anaysis and Identification Branch, Sacramento 
Brooker RW, Kikvidze Z, Pugnaire FI et al (2005) The importance of importance. Oikos 109:63-70

Brooker RW, Callaway RM, Cavieres LA et al (2009) Don't diss integration: a comment on Ricklefs's disintegrating communities. Am Nat 174:919-927. doi:10.1086/648058

Burns JH (2004) A comparison of invasive and non-invasive dayflowers (Commelinaceae) across experimental nutrient and water gradients. Divers Distrib 10:387-397. doi:10. 1111/j.1366-9516.2004.00105.x

Callaway RM, Aschehoug ET (2000) Invasive plants versus their new and old neighbors: a mechanism for exotic invasion. Science 290:521-523. doi:10.1126/science.290. 5491.521

Callaway RM, Kim J, Mahall BE (2006) Defoliation of Centaurea solstitialis stimulates compensatory growth and intensifies negative effects on neighbors. Biol Invasions 8:1389-1397. doi:10.1007/s10530-006-0003-8

Callihan RH, Prather TS, Northam FE (1993) Longevity of yellow starthistle (Centaurea solstitialis) achenes in soil. Weed Technol 7:33-35

Dawson W, Fischer M, van Kleunen M (2011) The maximum relative growth rate of common UK plant species is positively associated with their global invasiveness. Glob Ecol Biogeogr 20:299-306. doi:10.1111/j.1466-8238.2010. 00599.x

Garcia-Jacas N, Uysal T, Romashchenko K et al (2006) Centaurea revisited: a molecular survey of the Jacea group. Ann Bot 98:741-753

Garren JM, Strauss SY (2009) Population-level compensation by an invasive thistle thwarts biological control from seed predators. Ecol Appl 19:709-721

Gerlach JD, Rice KJ (2003) Testing life history correlates of invasiveness using congeneric plant species. Ecol Appl 13:167-179

Goldberg DE (1996) Simplifying the study of competition at the individual plant level: the consequences of distinguishing between effect and response for forest vegetation management. New Zealand J For Sci 26:19-38

Goldberg DE, Werner P (1983) Equivalece of competitors in plant communities: a null hypothesis and a field experimental approach. American J Bot 70:10981104

Greene DF, Johnson EA (1993) Seed mass and dispersal capacity in wind-dispersed diaspores. Oikos 67:69-74

Grotkopp E, Rejmánek M, Rost TL (2002) Toward a causal explanation of plant invasiveness: seedling growth and life-history strategies of 29 pine (Pinus) species. Am Nat 159:396-419. doi:10.1086/338995

Grotkopp E, Erskine-Ogden J, Rejmánek M (2010) Assessing potential invasiveness of woody horticultural plant species using seedling growth rate traits. J Appl Ecol 47:13201328. doi:10.1111/j.1365-2664.2010.01878.x

Guo Q, Brown JH, Valone TJ, Kachman SD (2000) Constraints of seed size on plant distribution and abundance. Ecology 81:2149-2155. doi:10.1890/0012-9658(2000)081[2149: COSSOP]2.0.CO;2

He WM, Zhang SX, Dong M (2003) Gas exchange, leaf structure, and hydraulic features in relation to sex, shoot form and leaf form in an evergreen shrub Sabina vulgaris in the semi-arid $\mathrm{Mu}$ Us Sandland in China. Photosynthetica 41:105-109
He W-M, Feng Y, Ridenour WM et al (2009) Novel weapons and invasion: biogeographic differences in the competitive effects of Centaurea maculosa and its root exudate $( \pm)$ catechin. Oecologia 159:803-815. doi:10.1007/s00442008-1234-4

Hierro JL, Maron JL, Callaway RM (2005) A biogeographical approach to plant invasions : the importance of studying exotics in their introduced and native range. J Ecol 93:5-15

Hierro JL, Villarreal D, Eren O et al (2006) Disturbance facilitates invasion: the effects are stronger abroad than at home. Am Nat 168:144-156. doi:10.1086/505767

Hierro JL, Eren Ö, Khetsuriani L et al (2009) Germination responses of an invasive species in native and non-native ranges. Oikos 118:529-538. doi:10.1111/j.1600-0706. 2009.17283.x

Imbert E (2002) Ecological consequences and ontogeny of seed heteromorphism. Perspect Plant Ecol Evol Syst 5:13-36. doi:10.1078/1433-8319-00021

Inderjit HE, Crocoll C, Bajpai D et al (2011) Volatile chemicals from leaf litter are associated with invasiveness of a neotropical weed in Asia. Ecology 92:316-324. doi:10.1890/ 10-0400.1

Kim YO, Lee EJ (2010) Comparison of phenolic compounds and the effects of invasive and native species in East Asia: support for the novel weapons hypothesis. Ecol Res 26:87-94. doi:10.1007/s11284-010-0762-7

Kulmatiski A, Beard KH, Stevens JR, Cobbold SM (2008) Plant-soil feedbacks: a meta-analytical review. Ecol Lett 11:980-992. doi:10.1111/j.1461-0248.2008.01209.x

Laird NM, Ware JH (1982) Random-effects models for longitudinal data. Biometrics 38:963-974

MacDougall AS, Turkington R (2004) Relative importance of suppression-based and tolerance-based competition in an invaded oak savanna. J Ecol 92:422-434. doi:10.1111/ j.0022-0477.2004.00886.x

Maddox DM, Mayfield A, Poritz NH (1985) Distribution of yellow starthistle (Centaurea solstitialis) and Russian knapweed (Centaurea repens). Weed Sci 33:315-327

Mandak B, Pysek P (2005) How does seed heteromorphism influence the life history stages of Atriplex sagittata (Chenopodiaceae)? Flora-Morphology, Distribution, Functional Ecology of Plants 200:516-526. doi:10.1016/ j.flora.2005.06.003

Munshaw MG, Lortie CJ (2010) Back to the basics: using density series to test regulation versus limitation for invasive plants. Plant Ecol 211:1-5. doi:10.1007/s11258-010-9764-3

Muth NZ, Pigliucci M (2006) Traits of invasives reconsidered: phenotypic comparisons of introduced invasive and introduced noninvasive plant species within two closely related clades. Am J Bot 93:188. doi:10.3732/ajb.93.2.188

Ortega YK, Pearson DE (2005) Weak vs. strong invaders of natural plant communities: assessing invasibility and impact. Ecol Appl 15:651-661. doi:10.1890/04-0119

Pearson DE, Callaway RM, Maron JL (2011) Biotic resistance via granivory: establishment by invasive, naturalized and native asters reflects generalist preference. Ecology 92: 1748-1757

Pennings SC, Callaway RM (1992) Salt marsh plant zonation: the relative importance of competition and physical factors. Ecology 73:681-690 
Pitcairn MJ, Young JA, Clements CD, Balciunas JOE (2002) Purple starthistle (Centaurea calcitrapa) seed germination. Weed Technol 16:452-456

Radford IJ, Dickinson KJM, Lord JM (2010) Does disturbance, competition or resource limitation underlie Hieracium lepidulum invasion in New Zealand? Mechanisms of establishment and persistence, and functional differentiation among invasive and native species. Aust Ecol 35:282-293. doi:10.1111/j.1442-9993.2009.02034.x

Reinhart KO, Callaway RM (2006) Soil biota and invasive plants. New Phytol 170:445-457. doi:10.1111/j.14698137.2006.01715.x

Ridenour WM, Vivanco JM, Feng Y et al (2008) No evidence for trade-offs: Centaurea plants from America are better competitors and defenders. Ecol Monogr 78:369-386

Robbins WW (1940) Alien plants growing without cultivation in California. Bulletin 637. California Agricultural Experiment Station, Berkeley

Roche CT, Thill DC, Shafii B (1997) Reproductive phenology in yellow starthistle (Centaurea solstitialis). Weed Sci 47:763-770

Skálová H, Pyšek P (2009) Germination and establishment of invasive and native Impatiens species in species-specific microsites. Neobiota 8:101-109

Sun M (1997) Population genetic structure of yellow starthistle (Centaurea solstitialis), a colonizing weed in the western United States. Can J Bot 75:1470-1478. doi:10.1139/ b97-861

Thompson K, Band SR, Hodgson JG (1993) Seed size and shape predict persistence in soil. Funct Ecol 7:236. doi:10.2307/ 2389893
Thorpe AS, Aschehoug ET, Atwater DZ, Callaway RM (2011) Interactions among plants and evolution. J Ecol 99: 729-740. doi:10.1111/j.1365-2745.2011.01802.x

van Kleunen M, Weber E, Fischer M (2010) A meta-analysis of trait differences between invasive and non-invasive plant species. Ecol Lett 13:235-245. doi:10.1111/j.14610248.2009.01418.x

Venable DL, Brown JS (1988) The selective interactions of dispersal, dormancy, and seed size as adaptations for reducing risk in variable environments. Am Nat 131: 360-384

Venable DL, Búrquez A, Corral G et al (1987) The ecology of seed heteromorphism in Heterosperma pinnatum in central Mexico. Ecology 68:65-76

Vilà M, Weiner J (2004) Are invasive plant species better competitors than native plant species? Evidence from pairwise experiments. Oikos 105:229-238. doi:10.1111/ j.0030-1299.2004.12682.x

Westoby M, Jurado E, Leishman M (1992) Comparative evolutionary ecology of seed size. Trends Ecol Evol 7: 368-372

Widmer TL, Guermache F, Dolgovskaia MY, Reznik SY (2007) Enhanced growth and seed properties in introduced vs. native populations of yellow starthistle (Centaurea solstitialis). Weed Sci 55:465-473

Williamson MH, Fitter A (1996) The characters of successful invaders. Biol Conserv 78:163-170. doi:10.1016/00063207(96)00025-0 